\title{
PERAN KOMUNIKASI PEMBANGUNAN DALAM PEMBERDAYAAN MASYARAKAT TANI DI REMBANG
}

\author{
Priska Nur Safitri, Najahan Musyafak \\ Fakultas Dakwah dan Komunikasi UIN Walisongo Semarang \\ Email: priscanasafitri07@gmail.com,najahan_musyafak@walisongo.ac.id
}

\begin{abstract}
7 his study aims to determine and analyze the role of development communication in the empowerment of peasant communities in Rembang. The focus of this study is on the role of agricultural development communication in the village of Dadap Mulya, Sarang, Rembang. Data collection techniques include documentation, observation, and interviews. This study concludes that communication carried out is still conventional logic so that it requires empowerment with a biotechnology digitization system. Technology with good accessibility will result in the availability of mass production. Based on real conditions, farmers must make better agricultural innovations. Therefore, the researchers offered a VAD Model for empowering peasant communities. VAD is considered suitable when applied to the quality of its human resources. Improving the quality of human resources can be done through socialization, training, teaching, and direct practice. The VAD model is considered suitable because in operation it involves physical to virtual, human to autonomus, and intermediacy to disentermediacy.
\end{abstract}

Keywords: Development Comunication, Peasant Empowerment, Virtual, Autonomous and Disintermediacy Model (VAD).

\begin{abstract}
ABSTRAK
$\mathrm{P}$ enelitian ini bertujuan mengetahui dan menganalisis peran komunikasi pembangunan dalam pemberdayaan masyarakat tani di Rembang. Fokus penelitian ini pada peran komunikasi pembangunan pertanian di Desa Dadap Mulya Sarang Rembang. Teknik pengumpulan data meliputi dokumentasi, observasi, dan interview. Penelitian ini menyimpulkan bahwa komunikasi yang dilakukan masih bersifat logic konvensional sehingga diperlukan pemberdayaan dengan sistem digitalisasi bioteknologi. Teknologi dengan accessibility yang baik akan menghasilkan ketersedian mass production. Berdasarkan kondisi rill, para petani harus melakukan inovasi-inovasi pertanian yang lebih baik lagi. Karenanya, peneliti menawarkan Model VAD untuk pemberdayaan masyarakat tani. VAD dipandang cocok diterapkan bilamana diikuti dengan kualitas sumber daya manusianya. Peningkatan kualitas SDM dapat dilakukan melalui sosialisasi, pelatihan, pengajaran, dan praktek langsung. Model VAD dianggap cocok karena dalam operasionalnya melibatkan physical ke virtual, human ke autonomus, dan intermediacy ke disentermediacy.
\end{abstract}

Kata kunci: Komunikasi Pembangunan, Pemberdayaan Petani, Model Virtual, Autonomus, Disintermediacy (VAD). 


\section{PENDAHULUAN}

Pembangunan tidak terlepas dari insfrastruktur yang memadai, sebagai laju pertumbuhan ekonomi bangsa. Pembangunan ekonomi pada masyarakat desa berfokus pada pertanian. Hal ini tidak bisa ditawar karena merupakan bagian dari pembangunan ekonomi secara nasional (Daryanto, 2011: 63). Data BPS Pusat bulan September 2017 menunjukkan masyarakat miskin Indonesia mencapai 26,58 juta orang $(10,12 \%)$ dari keseluruhan populasi penduduk. Sementara prosentase masyarakat miskin di pedesaan mencapai 13,47\% pada September 2017. Artinya dibutuhkan program yang dapat memberdayakan masyarakat desa di bidang pertanian, diperlukan terobosan yang dapat menyejahterakan masyarakat tani di desa.

Peringkat daya saing Indonesia dalam GSI (Global Competitiveness Index) yang dikeluarkan oleh World Economic Forum (WEF) tahun 2017 menunjukkan Indonesia menurun ke urutan 41. Tahun 2015-2016 Indonesia masih berada pada urutan ke 37 dari 138 negara. Indonesia kalah dengan negara Asia Tenggara lainnya Singapura, Malaysia, dan Thailand. Pemerintah melalui MP3EI (Master Plan Percepatan dan Perluasan Pembangunan Ekonomi Indonesia) dalam upaya percepatan dan perluasan yang terfokus, pertanian merupakan program unggulan yang di garap. Kesejahteraan ekonomi akan meningkatkan pendapatan perkapita dan indikator Indeks Pembangunan Manusia (IPM).

Pertanian adalah prioritas utama dari SDG's (Tujuan Pembangunan Berkelanjutan) yang berkaitan langsung dengan penghapusan kemiskinan dan kelaparan. Mengingat Indonesia negara yang memiliki keanekaragaman hayati besar setelah negara Brazil dan 800 spesies tumbuhan pangan. 70,8 Juta atau 37,1 persen dari 190. $923 \mathrm{Ha}$ di manfaatkan kegiatan budaya, perkebunan, hingga pertanian. Sementara 62,9 persen merupakan hutan.

Prof Klaus Schwab Ekonom dunia asal Jerman, sekaligus ketua WEF (World Economic Forum) mengatakan bahwa masyarakat revolusi industri dihadapkan pada kemudahan dalam inovasi karena jaringan teknologi digital yang mudah dan murah 'online.' Adopsi inovasi pertanian sebagai langkah dalam memanfaatkan ekosistem lokal maupun edukasi terhadap masyarakat baik sikap, perilaku, pengetahuan, keterampilan supaya memiliki daya saing yang kuat (Rasyidi dalam https:// www.researchgate.net.).

Pada Era revolusi Industri 4.0, pertanian perlu mengadopsi inovasi melalui koneksi jaringan, aplikasi hingga kerja manusia yang sedikit atau kecerdasan buatan, robotik yang telah menggantikan manusia. Inovasi pertanian berupa teknologi komunikasi yang tepat sangat dibutuhkan. Pada era Revolusi Industri 4.0 ini, sektor pertanian sangat bergerak lamban. 'dipaksa' mengikuti perkembangan 
teknologi untuk meningkatkan kualitas produk maupun jumlah hasil produksi.

Program adopsi inovasi bertujuan untuk meningkatkan proses pertanian yang lebih baik dan berorientasi hasil produksi yang maksimal. Melalui adopsi inovasi, komunikasi pembanguan masuk dan memiliki peran dalam menjembatani pembangunan di sektor pertanian, karena komunikasi pembangunan membuka pemahaman masyarakat secara pragmatis dalam menjalankan program pembangunan sehingga kontribusi komunikasi sebagai pembentuk tatanan perubahan di masyarakat dapat berjalan secara efektif dan berorientasi pembangunan.

Kebutuhan pangan yang tinggi dan tantangan revolusi industri 4.0, maupun target Tujuan Pembangunan Berkelanjutan, namun bagaimana dengan pengolah hasil pangan? Salah satu penghasil pangan adalah Desa Dadap Mulya Sarang Rembang., yang merupakan salah satu desa yang berada di Kecamatan Sarang Kabupaten Rembang dengan jumlah lahan yang luas, namun tanahnya tandus untuk pertanian, dengan sumber daya manusia yang masih berpendidikan rendah.

Kondisi lain yaitu peran penyuluh dalam mendampingi pelaku usaha tani yang belum maksimal tidak dilakukan secara intensif dan tidak berkesinambungan. Realitanya penyuluh hanya datang di saat musim hujan saja. Para penyuluh juga kurang dalam memberikan sosialisasi maupun belum membawakan inovasi pertanian yang dirasakan oleh masyarakat di Dadap Mulya. Selain itu permasalahan lain adalah pertanian yang masih logic konvensional dan belum terkoneksi dengan jaringan. Inilah beberapa permasalahan yang hendak penulis jelaskan dalam dalam tulisan ini, yang dirumuskan dengan judul, "Peran Komunikasi Pembangunan dalam Pemberdayaan Masyarakat Tani di Rembang."

\section{METODE PENELITIAN}

Penelitian ini merupakan penelitian kualitatif dengan pendekatan deskriptif melalui studi kasus. Studi kasus adalah penjelasan secara komprehensip mengenai kondisi sosial setempat berdasarkan fenomena yang ada di lapangan (Mulyana, 2001: 45). Studi kasus diawali dengan mempersiapkan bagaimana pengumpulan data, mengumpulkan keseluruhan data, melakukan analisis studi kasus, dan laporan penelitian (Yin: 2005). Melalui studi kasus akan didapatkan sebuah kerangka berdasarkan fenomena di wilayah penelitian. Peneliti akan mengilustrasikan category sehingga ada keterkaitan antar category dalam kerangka menyusun bagaimana peran komunikasi pembangunan untuk pemberdayaan. Studi kasus dimaksudkan supaya situasi sosial yang ada di lapangan dapat dicarikan alternatif peran komunikasi pembangunan untuk pemberdayaan dengan orientasi kesejahteraan masyarakat kedepannya.

Peran komunikasi pembangunan dalam pemberdayaan masyarakat menjembatani kesenjangan komunikasi baik masyarakat tani, penyuluh maupun pemerintah. Berdasarkan kecenderungan penelitian, penelitian ini fokus pada studi 
Peran Komunikasi Pembangunan Dalam ...hal. 46-59

tokoh dan pemberdayaan di mana komunikasi pembangunan masuk dalam ranah penelitian tersebut. Wilayah penelitian/sampling penelitian dalam penelitian ini, menggunakan sample purposif (purposive sampling) dalam menentukan objek penelitian. Purposive sampling dilakukan dengan pertimbangan alasan dan sumber sesuai fokus penelitian (Arikunto, 1998: 127). Sample yang dipilih adalah Desa Dadap Mulya Sarang Rembang. Desa tersebut merupakan salah satu desa yang berada di Kecamatan Sarang Kabupaten Rembang. Desa ini sangat panas serta tanahnya tandus, tetapi lahan pertanian di desa ini sangat luas.

Pengumpulan data dilakukan dengan menggabungkan beberapa teknik yaitu dokumentasi, observasi, dan wawancara. Observasi dilakukan peneliti untuk melihat bagaimana gambaran pertanian di Dadap Mulya. Dokumentasi diperlukan untuk pengujian suatu fenomena, dalam hal ini adalah literatur yang mendukung dan berkaitan dengan tujuan penelitian (Moleong, 2011: 216).

Sementara itu wawancara dilakukan untuk mendapatkan data secara langsung terhadap objek penelitian. Wawancara dalam hal ini dilakukan terhadap subjek penelitian yaitu tokoh masyarakat setempat tetapi melakukan contoh rill pertanian, yaitu Satrio Utomo di Dadap Mulya. Kegiatan wawancara meliputi aspek peran komunikasi pembangunan dalam pemberdayaan maupun inovasi dalam pertanian.

\section{PEMBAHASAN}

\section{Tinjauan Komunikasi Pembangunan}

Wakil Presiden Bank Dunia mengatakan bahwa kesemuanya membutuhkan komunikasi termasuk pekerjaan analitis dan penasehat juga tidak terlepas dari komponen komunikasi termasuk mengenai kemiskinan, komunikasi sangat penting masuk sebagai bagian utama baik dalam kegiatan, desain maupun implementasinya. Reformasi kebijakan juga bagian dari operasi komunikasi, yang semuanya digerakkan oleh hasil dan ukuran dari dampak pembangunan (Mefaopulus, 2008: 214-215).

"is a process of consensus building and resistence. It is not a linear process, but must be historically grounded, culturally sensitive, and multifaceted, with attention to all the political, economic, and ideological structures and processes that comprise society" (Molkote, 2001: 38).

Artinya bahwa komunikasi pembangunan merupakan sebuah proses yang dalam pelaksanaannya harus sejalan dengan apa yang sudah menjadi tradisi, ideologi, politik, ekonomi masyarakat itu sendiri. Hal ini sama dengan yang diungkapkan oleh (Dilla, 2012: 119) bahwa orientasi komunikasi pembangunan adalah perubahan terhadap komunitas lokal yakni masyarakat desa, dalam hal ini petani karena mayoritas desa penduduknya tani. Melalui pendekatan komunikasi pembangunan yang berkonsentrasi pada kegiatan, komunikasi berjalan dalam menyalurkan gagasan, ide, inovasi baru maupun sebuah produk.

Komunikasi dilakukan supaya ada pengembangan untuk pemberdayaan masyarakat (community development) atau dulu dikenal community resource 
development, rural areas development, community economicdevelopment, rural revitalisation dan community development. Community development merupakan penggabungan konsep community (tingkat hubungan sosial) dan development (perubahan yang sudah di planning). Pengembangan bila dilakukan terfokus, terprogram, dikendalikan dengan baik akan mampu memberikan solusi bagi masalah terkait isu kesejahteraan masyarakat. Hal ini pernah disuarakan oleh PBB bahwa community development adalah kontribusi pada gerakan sosial dengan perubahan utama pada pembangunan desa terutama di negara berkembang (Toni, 2014: 29-30). Pemberdayaan masyarakat berdampak pada peningkatan ekonomi masyarakat, tetapi juga berdampak pada lingkungan, struktur sosial, sikap masyarakat itu sendiri.

\section{Pemberdayaan Masyarakat dengan}

\section{Adopsi Inovasi}

Konsep

membutuhkan perencanaan dalam memecahkan problematika sehingga muncul solusi. Perencanaan secara top down dapat menerapkan beberapa model komunikasi. Terdapat tiga model komunikasi yang dipandang mampu memengaruhi praktik inovasi, yaitu: Pertama, model objektif atau transmisi. Kedua, model subjektif atau berorientasi penerima. Ketiga, model jaringan atau negosiasi (Leeuwis, 2009: 199). Pemberdayaan masyarakat tani juga harus melalui irigasi untuk meningkatkan hasil produksi pertanian. Melalui ini, potensi produksi di sektor agraris cukup signifikan dalam menyejahterakan masyarakat yang akan memungkinkan pertumbuhan dalam hasil maupun profitabilitas produksi pertanian, meningkatkan kesuburan tanah maupun penahanan degradasi tanah, membantu menjaga kelembapan tanah dan meningkatkan kesuburan yang tentunya akan berpengaruh pada pertumbuhan hasil panen (Kiselev, 2016: 549).

Komunikasi berhasil dalam pemberdayaan masyarakat tani bilamana menghasilkan inovasi (Rogers, 1983: 162). Proses pengembangan inovasi terdiri dari semua keputusan, kegiatan dan dampaknya yang terjadi dari pangkuan kebutuhan atau masalah, melalui penelitian, pengembangan dan komersialisasi sebuah inovasi. Konsekuensinya ialah difusi inovasi dapat diimplementasikan. Kedua, proses pengembangan inovasi yang didefinisikan sebagai proses menempatkan ide baru ke dalam bentuk yang diharapkan dapat menemukan kebutuhan potensial pengadopsi.

Ketiga, komersialisasi didefinisikan sebagai produksi, manufaktur, pengemasan, pemasaran, dan distribusi produk yang mewujudkan inovasi. Keempat, komersialisasi dapat dilakukan oleh perusahaan swasta yang merupakan poin penting pengembangan inovasi. Inovasi sangat dibutuhkan untuk potensi pengadopsi sebagai arah perubahan. Kelima, lanjutan uji klinis berupa percobaan ilmiah yang dirancang untuk menentukan secara prospektif efek dari inovasi apakah ada kemajuan, keamanan, dan sejenisnya. Keenam, pada akhirnya inovasi berdifusi. 
Peran Komunikasi Pembangunan Dalam ...hal. 46-59

Tingkat inovasi ini dianggap memiliki keunggulan dan keuntungan dilihat dari segi ekonomi. Pertama, tingkatan seorang individu dalam memandang inovasi tergantung tingkat kecepatan adopsi yang dilakukan. Kedua, kompatibilitas, bahwa inovasi dirasakan konsisten dengan nilai yang ada, pengalaman masa lalu serta kebutuhan pengadopsi potensial. Adopsi yang tidak kompatibel akan mengharuskan adopsi yang baru. Ketiga, kompleksitas adalah sejauh mana inovasi dimengerti dan digunkan. Keempat, trialability adalah sejauhmana inovasi dapat diuji-cobakan. Kelima, ability adalah hasil dari inovasi yang dilakukan dalam hal ini di sektor pertanian (Rogers, 1983: 15).

Inovasi tidak terlepas dari pemuka pendapat (opinion leader) sebagai agen perubahan. Opinion leader memiliki role terhadap proses inovasi di sektor pertanian. Untuk membujuk, memberikan pengetahuan tentang inovasi. Opinion leader adalah sejauh mana individu tersebut mampu memengaruhi sikap, perilaku, dan memberikan contoh-contoh pertanian yang baik. Opinion leader sebagai social perception, ability in abstract thinking, emotional stability, sebagai pembina, pengarah terhadap inovasi di sektor pertanian serta dianggap sebagai media exposure (Nuruddin, 2007: 160).

Adapun karakteristik dalam inovasi pertanian yaitu: Pertama, keterbukaan tentang inovasi pertanian. Kedua, tingkat adopsi berbagai inovasi dalam sistem sosial. Ketiga, inovatif. Keempat, kepemimpinan opini. Kelima, siapa yang berinteraksi dengan siapa dalam jaringan difusi. Keenam, tingat adopsi dalam sistem sosial yang berbeda. Ketujuh, penggunaan saluran komunikasi. Kedelapan, konsekuensi dari inovasi (Rogers, 1983: 86-87).

\section{Temuan dan Hasil Penelitian}

Se,cara geografis Desa Dadap Mulyo berada di Kecamatan Sarang Kabupaten Rembang Jawa Tengah. Batas wilayah sebelah utara adalah Desa Kalipang, batas selatan adalah Desa Nglojo. Batas barat adalah Desa Gunung Mulya, dan sebelah timur adalah Desa Babak Tulung. Desa ini memiliki lahan petanian yang luas tetapi sangat panas, serta tanahnya tandus. Jarak yang ditempu untuk mencapai kecamatan, 5 $\mathrm{km}$. Sementara untuk mencapai kabupaten $50 \mathrm{~km}$, dan jarak yang ditempuh untuk menuju ibu kota provinsi adalah $160 \mathrm{~km}$.

Desa Dadap Mulya memiliki luas tanah 174.028 Ha. Ketinggian tanah dari permukaan air laut adalah $5 \mathrm{Mdl}$, dan curah hujan 9,93 Mm, dengan suhu udara rata-rata $23 \mathrm{C} / \mathrm{d} 30 \mathrm{C}$. Jumlah penduduk sebanyak 2.132 orang dengan 724 kepala keluarga. Laki-laki berjumlah 1.077 orang dan perempuan berjumlah 1.055 orang, dan semuanya beragama Islam, serta hanya 16 orang yang menempuh pendidikan di Perguruan Tinggi. Masyarakat Dadap Mulya pertaniannya terdiri atas padi sebagai tanaman untuk memenuhi kehidupan, sayur-sayuran, buah-buahan, padi dan pala wija hanya sebagian kecil. Adapun dalam bercocok tanam, masyarakat lebih mengarah kepada padi dengan $160 \mathrm{Ha}$ atau 800 ton. 
Pertanian di Desa Dadap Mulya Sarang Rembang dalam sejarah perkembangannya mengalami pasang surut. Penelitian yang peneliti susun ini sangat ditentukan oleh situasi sosial dan situasi yang ada di lapangan. Berbagai klasifikasi ditemukan, disusun, dan dianalisa untuk menemukan konstruk yang penting dalam konsep penelitian. Berdasarkan situasi sosial terlihat bahwa masyarakat tani di Desa Dadap Mulya Sarang penting mendapat perhatian karena adanya gap yang sangat signifikan antara petani kaya dengan luas ladang yang banyak dan petani miskin dengan ladang yang sempit.

Pertanian di Desa Dadap Mulya Sarang Rembang adalah sektor utama pendapatan masyarakat. Untuk itu pertanian menjadi hal yang penting karena menyangkut dengan kesejahteraan masyarakat. Untuk mewujudkan kesejahteran masyarakat dibutuhkan suatu upaya agar pertanian bisa produktif, maka pemberdayaan perlu dilakukan dengan baik. Suasana pertanian di Desa Dadap Mulya mengalami perubahan yang drastis berkat sentuhan tangan pemuda bernama Satrio Utomo, laki-laki berusia 29 tahun. Setelah lulus Sarjana dari Pendidikan Geografi Universitas Negeri Semarang, memutuskan berhenti bekerja di Bank Swasta. Satrio kembali ke kampung halamannya fokus pada usaha pertanian. Dari Satrio keberanian melakukan terobosan dimulai ide dan inovasi dilakukan. Kehadiran Satrio selama empat tahun produksi hasil pertanian meningkat.

Bila sejak tahun 1970an masyarakat Dadap Mulya masih bergantung pada pupuk kimia, hal ini dalam jangka pendek akan menyuburkan tanaman, tetapi dalam jangka panjang akan membuat tanah menjadi tidak subur (Wawancara dengan Satrio Utomo, pada 29 Oktober 2018). Satrio berhasil mengubah hal tersebut, dengan memilih menggunakan bahan organik tanah dan memperbanyak kompos. Kompos juga didapat mudah (tidak beli) karena hampir setiap rumah punya ternak, jadi kotoran ternak tersebut digunakan untuk tanaman supaya pertanian subur serta mengurangi penggunaan pupuk kimia maupun pestisida, yang dalam jangka panjang akan berdampak buruk terhadap tanah.

Selain itu tanah pantura Desa Dadap Mulya Sarang Rembang yang dikenal dengan tanah yang gersang dan tandus, berhasil direkayasa menjadi lahan irigasi yang digunakan untuk pembajakan tanaman sehingga dapat menghemat air hingga $50 \%$. Irigasi putar yang di cetuskan oleh Satrio sangat cocok karena iklim Desa Dadap Mulya yang panas dan minim air tawar.

Irigasi putar dihubungkan dengan sumur bor yang diciptakan Satrio guna mengaliri area sawah, supaya tidak bergantung pada hujan. Irigasi putar adalah pengembangan irigasi pertanian dengan tenaga pompa listrik sibel bukan diesel, yang dilakukan Satrio di Desa Dadap Mulya Sarang Rembang. Hal ini dilakukan supaya petani dapat mandiri dan menyadari bahwa pertanian adalah suatu keberlanjutan. Motto Satrio, dan kepeduliannya terhadap pertanian diharapkan dapat menular terhadap masyarakat Dadap Mulya, karena pertanian adalah sektor pangan nasional. 
Peran Komunikasi Pembangunan Dalam ...hal. 46-59

Perjalanan pertanian di Desa Dadap Mulya sudah melakukan evolusi adopsi inovasi pertanian. Masyarakat berkembang secara dinamis yang mengarah pada tujuan yang lebih baik. Satrio mengakomodasi bentuk pertanian yang ramah lingkungan, tetapi mampu meningkatkan hasil pertanian secara signifikan. Ini menempatkan Satrio sebagai figur yang dicontoh di masyarakat karena mampu melakukan inovasi pertanian dalam tataran mikro ke arah kesejahteraan masyarakat yang lebih baik.

Melalui inovasi akan membawa pertanian tidak hanya berorientasi pada kesejahteraan masyarakat saja, tetapi mampu melakukan pemberdayaan ke arah yang lebih luas sebagaimana diterapkan pada daerah bahkan negaranegara lain karena output dari komunikasi pembangunan pertanian adalah pemberdayaan masyarakat tani bukan hanya mengubah pandangan tentang inovasi tetapi juga berimplikasi pada peran komunikasi yang interaktif, konstruktif, evolusioner. Secara implisit komunikasi mendesain inovasi.

Penelitian ini menemukan bahwa komunikasi pembangunan yang dilakukan untuk pemberdayaan masyarakat tani dengan bentuk komunikasi 'njagong' dan 'getok tular' antar warga atau dikenal dengan istilah 'Word of Mouth'. Word of Mouth (WoM) adalah memberikan sosialisasi tidak resmi kepada warga sambil ngobrol-ngobrol bersama. Word of Mouth adalah bentuk komunikasi mulut ke mulut, yang menggunakan biaya kecil atau bisa tidak mengeluarkan biaya. Bahwa dalam sebuah komunitas tradisional unsur kedekatan siapa yang menyampaikan juga memengaruhi pesan diterima atau tidaknya. Kotler (1998) menyatakan bahwa WoM adalah proses komunikasi dengan memberikan rekomendasi baik personal maupun kelompok. WoM juga menunjukkan keterkaitan hubungan yang dekat antara komunikan dan komunikatornya.

Pelaksanaan pertanian di Desa Dadap Mulya belum sepenuhnya modern tetapi masih 'logic konvensional' menuju 'semi modern.' Hal ini dapat dilihat dari alat-alat yang digunakan belum sepenuhnya modern, tetapi masih banyak yang tradisional (masih butuh sentuhan tangan manusia). Dalam menanam padi atau dikenal dengan 'tandur' masih manual belum menggunakan alat/ teknologi. Sementara untuk hasil pemanenan sudah menggunkan teknologi 'blower'.

Pertanian di Dadap Mulya, sebagai awal pemodalan dalam bertani juga masih dilakukan sendiri. Artinya belum ada peran pemerintah yang memberikan pemodalan di awal bercocok tanam. Tetapi petani melakukan strategi dengan menjual ternak sebagai modal awal pertanian, atau pinjam ke bank, meskipun berbunga. Penyuluh pertanian dari Dinas Pertanian Kabupaten Rembang juga memberikan sosialisasi kepada warga mengenai penyakit hama terhadap tanaman, cara mengatasi hama tanaman hingga membangun akses pertanian. Akan tetapi sosialisasi ini kurang intensif karena hanya dilakukan sekedar sosialisasi saja, belum ada tindakan konkretnya serta dilakukan secara musiman serta tidak keberlanjutan. 
Setiap bidang pertanian yang dijalankan oleh petani belum tersambung secara 'online' untuk langsung menghubungkan antara penyuluh pertanian, petani, distributor, dan lain sebagainya. Lemahnya antar elemen untuk menghubungkan jaringan terkendala mengingat berdasarkan monografi desa Dadap Mulya, sumber daya manusianya yang berpendidikan tinggi sangat kurang dan belum banyak lulusan perguruan dan baru beberapa saja masih dalam studi di perguruan tinggi. Artinya komunikasi yang dilakukan masih face to face, 'Word of Mouth' belum terkoneksi dengan semua pihak secara online. Komunikasi pembangunan yang dilakukan saat ini hanya fokus bagaimana meningkatkan kesejahteraan masyarakat. Kebutuhan jangka panjang harus mampu menggunakan teknonogi informasi supaya waktu bercocok tanam singkat dan hasil panen produktif.

Peran komunikasi pembangunan konteks ini adalah kegiatan yang berupaya untuk pemberdayaan masyarakat yang harus terkoneksi dengan jaringan internet. Maka pembangunan masyarakat tani harus berorientasi pada edukasi bahwa pertanian sangat berkelanjutan baik itu pemberdayaan, kesejahteraan masyarakat, dan tersambungnya teknologi dan informasi. Keberlanjutan pertanian (suistainable agriculture) adalah produksi hasil petanian dengan pemanfaatan sumber daya. Aspek keberlanjutan agriculture meliputi faktor ekonomi untuk memperoleh pendapatan, faktor sosial untuk kesejahteraan, faktor lingkungan untuk stabilitas alam ekosistem.

Pertanian di Dadap Mulya Sarang Rembang adalah wujud pertanian pesisir yang berada di pantai utara pulau Jawa yang memiliki nilai strategis dalam partisipasi pembangunan nasional di Indonesia terhadap sektor pertanian dengan peningkatan kualitas sumber daya manusia untuk merumuskan kualitas produksi maupun hasil yang dicapai.

Berdasarkan observasi peneliti, perkembangan pertanian di Desa Dadap Mulya Sarang Rembang dilihat dari dinamika kondisi sosial masyarakat sudah mengalami peningkatan yang berarti/cukup signifikan. Dapat dilihat bahwa tanah gersang dapat ditanami padi, dari yang semula sekali panen dalam setahun menjadi dua kali panen dalam setahun. Hingga pembutan 'sumur bor' yang kemudian dialirkan ke lahanlahan pertanian dengan sistem irigasi putar.

Selain itu perkembangan juga terlihat bahwa masyarakat tidak hanya menanam padi saja. Mereka juga melakukan upaya dengan menanam berbagai sayuran seperti bayam, kangkung, jagung di pinggiran lahan kosong 'tanggul' yang hal itu dapat dipanen hampir setiap hari. Ini menunjukkan bahwa pengembangan ekonomi sudah berjalan dengan cukup baik. Hal ini sejalan dengan apa yang diutarakan oleh Everet M. Rogers bahwa memberdayakan masyarakat dibutuhkan inovasi. Proses pengembangan inovasi terdiri dari semua keputusan, kegiatan dan dampaknya yang terjadi dari pangkuan kebutuhan atau masalah, 
Peran Komunikasi Pembangunan Dalam ...hal. 46-59

melalui penelitian, pengembangan dan komersialisasi sebuah inovasi, yang konsekuensinya difusi inovasi dapat diimplementasikan (Rogers. 1983: 162).

Sebagaimana yang dilakukan Satrio dalam perkembangan inovasi pertanian menempatkan dirinya sebagai opinion leader dalam komunitas masyarakat di Desa Dadap Mulya. Hal ini dapat dilihat dari inovasi yang dilakukan, yaitu ide, gagasan, praktek yang sudah diterapkan selama empat tahun. Dengan perkembangan teknologi yang dinamis, apa yang dilakukan Satrio belum cukup, karena Indonesia memasuki Revolusi Industri 4.0. Dengan perkembangan teknologi dan informasi, adalah suatu keniscayaan para petani harus 'melek teknologi.' Dengan sistem teknologi yang terstruktur maka akan terhubung langsung dengan instansi terkait, baik itu pemerintah, steakholder, dan konsumen sebagai upaya penggunaan teknologi guna memperlancar dalam mewujudkan proses komunikasi yang lebih baik.

Dalam observasi yang dilakukan peneliti, terdapat beberapa potensi yang dimiliki oleh Desa Dadap Mulya Sarang Rembang terhadap pertanian. Maka peneliti mengambil kesimpulan bahwa pertanian di Desa Dadap Mulya Sarang Rembang harus melakukan keberanian, terobosan untuk pemberdayakan petani. Terobosan ini berupa inovasi-inovasi dalam bidang pertanian dengan melihat kualitas sumber daya manusianya, motivasi terhadap petani. Masyarakat tani harus menyadari bahwa pertanian adalah keberlanjutan yang harus terus berkembang dan butuh pengembanganpengembangan pertanian berupa inovasi pertanian, karena yang bergerak di sektor pangan.

Era Revolusi Industri 4.0 bukan mengenai produksi pertanian yang tidak dibutuhkan tetapi tenaganya telah digantikan. Tenaga manusia sangat sedikit digunakan dan sudah menggunakan teknologi. Saat ini yang terpenting adalah speed dan kreatifitas, karena faktor lahan, tenaga kerja, dan kekayaan hayati bukan lagi hal utama. Karenanya, dalam mewujudkan revolusi agrikultur, dibutuhkan digitalisasi, efektifitas dan bioteknologi yang serba cepat dan modern.

Bila pertanian dengan pemikiran logic konvensional masih di pertahankan maka pertanian akan tertinggal. Peran komunikasi pembangunan sangat dibutuhkan dalam hal ini, tidak terlepas dari peran sentral penyuluh pertanian. Penyuluh pertanian harus melakukan penyuluhan intensif, rutin, berkala, dan berkesinambungan, bukan hanya sosiaslisasi semata tetapi juga memberikan pelatihan dan pengenalan teknologi terhadap masyarakat tani, di mana sistem pedesaan yang masih menganut tradisi, di sinilah penyuluh perlu menggandeng 'opinion leader' Desa Dadap Mulya.

Ada dua hal yang menjadikan pertanian di Desa Dadap Mulya ini membutuhkan peran komunikasi dengan sistem teknologi informasi. Pertama, komunikasi yang ada saat ini masih tradisional (face to face) dan (Word of Mouth). Hal ini belum menyelesaikan problematika dan dinamika masyarakat desa yang ada. Maka inovasi terhadap pertanian perlu adanya. Dengan melakukan adopsi teknologi baru. Antara 
penyuluh pertanian, aparat desa, steakholder, petani, opinion leader harus bersinergi bersama dalam mencari solusi terkait pertanian untuk mendapatkan jumlah hasil panen yang banyak, dan kualitas panen yang baik.

Dalam revolusi Industri 4.0, pertanian harus terkoneksi dengan Internet of Things (IoT), karena konsep IoT menggunakan teknologi komunikasi yang dapat memungkinkan elemenelemen terhubung dengan jaringan di sekitar kita kapan saja dan di mana saja. Hal ini perlu dilakukan untuk mewujudkan target SDG's terhadap sektor pertanian karena hal ini langsung terkoneksi antara pemerintah, penyuluh pertanian, steakholder, petani, konsumen dan lain-lain. Kedua, kualitas sumber daya manusia yang rendah menjadi hambatan, baik edukasi, sosialisasi pertanian maupun pengenalan bioteknologi. Bila prasyarat utama pertanian adalah peningkatan jumlah produksi pertanian, maka perlu Training of Trainers untuk para tani bukan hanya sosialisasi yang dilakukan oleh penyuluh semata, tetapi juga pelatihan, pengajaran, dan praktek. Supaya keberhasilan pertanian mutlak adanya perlu sinergi dari Kementerian Pertanian setempat, Kementrian Komunikasi, aparat desa maupun instansi terkait supaya Indonesia dapat mewujudkan Tujuan Pembangunan Berkelanjutan (SDG's) tahun 2030 mendatang. Pekerjaan rumah Indonesia saat ini adalah masih mengimport beras dari negara tetangga, yaitu Vietnam.

Peneliti memandang bahwa dalam mewujudkan tujuan pembangunan berkelanjutan di Desa Dadap Mulya perlu adanya ToT yang bukan hanya sosialisasi semata tetapi juga, pelatihan, pengajaran, dan praktek untuk para petani. Training of Trainers yang bersinergi dari para akademisi, Kementrian Pertanian, Penyuluh Pertanian, Kementrian Komunikasi sebagai penghubung karena sudah terkoneksi dengan Internet of Things, Steakholder, petani dan lain-lain, sangatlah diperlukan.

Berdasarkan pada realitas tersebut peneliti menawarkan sebuah bentuk model alternatif pemberdayaan masyarakat pertanian di Desa Dadap Mulya Sarang Rembang, dalam memenuhi kebutuhan pangan, dan menghadapi Revolusi Industri 4.0, sebagaimana memenuhi target SDG's 2030 mendatang. Model VAD, peneliti pandang cocok untuk diterapkan bilamana diikuti dengan kualitas sumber daya manusianya.

Model VAD merupakan bentuk model dari pertanian yang semula masih dilakukan secara physical secara keseluruhan, tetapi dengan bantuan teknologi dapat dilakukan melalui virtual. Bahwa pembangunan dari pertanian adalah human bukan komoditi maka perlu pendidikan, kedisiplinan, dan partisipasi sehingga peluang menumbuhkembangkan pertanian melalui autonomous dipandang tercipta karena menyangkut pembangunan daerah. Selain itu, kegiatan pertanian yang dilakukan seluruhnya melalui intermediacy dengan sebuah pengelolan informasi dapat dilakukan dengan disentermediay. Dengan demikian peluang menjadi terbuka dan masyarakat dapat membuka partisipasi secara luas 
Peran Komunikasi Pembangunan Dalam ...hal. 46-59

dan dapat memantau kebijakan pemerintah. Hal ini karena petani secara mandiri tentu mengerti kemampuan dirinya terhadap masalah yang dihadapi dan secara tidak langsung mampu mengidentifikasi solusinya.

Model VAD tersebut peneliti anggap cocok karena dalam operasionalnya melibatkan physical ke virtual, human ke autonomus, dan intermediacy ke disentermediacy. Peningkatan kualitas SDM, dapat dilakukan melalui sosialisasi, pelatihan, pengajaran, dan praktek secara langsung sehingga kualitas sumber daya manusia menjadi lebih baik, dan tentunya akan mendapatkan output dari pertanian yang maksimal untuk kesejahteraan petani.

\section{KESIMPULAN DAN SARAN}

$\begin{array}{lcr}\text { Penelitian } & \text { mengenai } & \text { peran } \\ \text { komunikasi } & \text { pembangunan } & \text { dalam } \\ \text { pemberdayan } & \text { masyarakat tani di } \\ \text { Rembang ini } & \text { mengahasilkan } & \text { simpulan } \\ \text { sebagai berikut: } & \end{array}$

1. Keberadaan pertanian dan luasnya areal tanah di Desa Dadap Mulya terhadap masyarakat memiliki nilai dinamis positif karena sebagai kelangsungan hidup masyarakat yang berorientasi pada kesejahteraan. Perkembangan pertanian saat di Dadap Mulya mengalami perkembangan yang pesat. Hal ini dapat dilihat dari adanya irigasi putar, meningkatnya hasil pertanian, dan tanah yang gersang menjadi subur. Akan tetapi, observasi yang dilakukan oleh peneliti menemukan bahwa komunikasi yang dilakukan masih logic konvensional, yang dalam konteks era revolusi industri 4.0, masih sangat ketinggalan. Oleh karena itu perlu pemberdayaan dengan sistem digitalisasi bioteknologi. Teknologi dengan accessibility yang baik akan menghasilkan ketersedian mass production.

2. Kondisi di Dadap Mulya terhadap pertanian memiliki potensi dan peluang besar. Maka peneliti berkesimpulan bahwa pertanian di Desa Dadap Mulya ini membutuhkan sebuah peran komunikasi pembangunan dengan sistem teknologi informasi. Pertama, komunikasi yang ada saat ini masih tradisional (face to face) dan 'Word of Mounth'. Hal ini belum menyelesaikan permasalahan yang ada. Revolusi Industri 4.0, pertanian harus terkoneksi Internet of Things. Hal ini perlu dilakukan untuk mewujudkan target SDG's terhadap sektor pertanian karena hal ini langsung terkoneksi antara pemerintah, penyuluh pertanian, steakholder, petani, konsumen dan lain-lain.

Kedua, Kualitas sumber daya manusia yang rendah menjadi hambatan. Bila prasyarat utama pertanian adalah peningkatan jumlah produsi pertanian, maka perlu Training of Trainers untuk para tani, jadi bukan hanya sosialisasi yang dilakukan oleh penyuluh semata, tetapi juga pelatihan, pengajaran, dan praktek. Perlu pula sinergi dari Kementerian Pertanian setempat, Kementrian Komunikasi, aparat desa maupun instansi terkait supaya 
Priska Nur Safitri, Najahan Musyafak

Indonesia dapat mewujudkan

Tujuan Pembangunan Berkelanjutan (SDG's) tahun 2030 mendatang.

3. Peneliti menawarkan sebuah bentuk model alternatif pemberdayaan masyarakat pertanian di Desa Dadap Mulya Sarang Rembang, dalam memenuhi kebutuhan pangan, dan menghadapi Revolusi Industri 4.0, sebagaimana target SDG's 2030 mendatang, yaitu melalui Model VAD, yang dalam operasionalnya melibatkan physical ke virtual, auman ke Autonomus, dan intermediacy ke disentermediacy.

Direkomendasikan kepada penggerak pertanian di Dadap Mulya Sarang Rembang yaitu penyuluh untuk lebih intensif lagi dalam melakukan sosialisasi dan diharapkan dapat memberikan terobosan, wawasan terhadap masyarakat supaya pembangunan pertanian dapat berkelanjutan. Selain itu, pimpinan desa, Opinion Leader untuk lebih aktif lagi dalam melakukan penyadaran terhadap masyarakat karena keberhasilan pertanian juga akan menuju kesejahteraan bersama.

\section{DAFTAR PUSTAKA}

Arikunto, S. (1998). Prosedur Penelitian: Suatu Pendekatan Praktek, Edisi Revisi IV. Jakarta: Rineka Cipta.

Daryanto, A. (2011). Penguatan Ketahanan Masyarakat Desa (Community Resilience) Dalam Pembangunan Sosial Ekonomi Desa, dalam 'Menuju Desa 2030'. Bogor: Pohon Cahaya.

\section{Dilla, S. (2012). Komunikasi Pembangunan: Pendekatan}

Terpadu. Bandung: Simbiosa Rekatama Media.

Hanari, N. Masa Depan Pertanian Indonesia? Tersedia di http://nuhfil.lecture.ub.ac.id.

Kiselev, S.V. A.S. Strokov, A. Yu. Studies on Russian Economic Development. Jurnal Pleiades Publishing, Vol 27 No. 5 (2016).

Kotler,P. Garry A. (1998). Dasar-Dasar Pemasaran. Jakarta: Prenhallinda.

Leeuwis, C. 2009. Komunikasi Untuk Inovasi Pedesaan: Berfikir Kembali Tentang Penyuluhan Pertanian. Jogyakarta: Kanisius. , C. (2004) Changing Views of Agricultural Innovation: Implications for Communicative Intervention and Science, Communication and Innovation Studies.Wageningen: University, the Netherlands.

Master Plan Percepatan dan Perluasan pembangunan Ekonomi Indonesia (MP3EI) 2011-2025, Tersedia di https://www.bappenas.go.id.

Mefaopulus, P. (2008). Development Communication Sourcebook Broadening the Boundaries of Communication. Washington D.C.: World Bank.

Melkote, S. (2001). Communication for Development in the Third World: Theory And Paractice for Empowerment. New Delhi: Sage Publications.

Moleong, J. (2011). Metode Penelitian Kualitatif: Edisi Revisi. Bandung: Remaja Rosda Karya. 
Mulyana, D. (2001). Metode Penelitian

Kualitatif: Paradigma Baru Ilmu

Komunikasi dan Ilmu Sosial

Lainnya. Bandung: Remaja

Rosdakarya.

Monografi Desa Dadap Mulya

Kecamatan Sarang Kabupaten

Rembang, Tahun 2017.

Nasution, S. (2017). Memperbaiki Daya

Saing Indonesia, dalam

Direktorat Jendral Kelembagaan

IPTEK dan DIKTI

(Kelembagaan Riset, Teknologi, dan Pendidikan Tinggi, Pada 11

April 2017, Tersedia di http://kelembagaan.ristekdikti.go. id.

Nurudin. (2007). Sistem Komunikasi Indonesia. Jakarta: Raja Grafindo Persada.

Rogers, M. (1983). Diffusion Of Innovations: Third Edition, New York: The Free Pres A Division of Macmillan Publishing.

Rosyadi, S. Revolusi Industri 4.0: Peluang dan Tantangan Alumni Universitas Terbuka. Dosen Fakultas Ilmu Sosial dan Politik Universitas Soedirman. Tersedia di https://www.researchgate.net.

Toni, N. (2014). Pengembangan Masyarakat. Jakarta: Kerja Sama Antara Departemen Sains Komunikasi dan Pengembangan Masyarakat Ekologi IPB dengan Yayasan Pustaka Obor Indonesia.

Wawancara dengan Satrio Utomo, Tanggal 29 Oktober 2018 di Sarang Rembang.

Yin, R.K. (2005). Studi Kasus, Desain dan Metode, Edisi Revisi, Jakarta: Raja Grafindo Persada. 